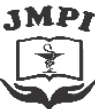

Jurnal Mandala Pharmacon Indonesia, Vol 4.No.2 Desember 2018

Avaiable online at www.jurnal-pharmaconmw.com/jmpi

$p$-ISSN : 2442-6032

e-ISSN : 2598-9979

\title{
Isolasi Dan Identifikasi Fungi Endofit Daun Jambu Mete (Anacardium occidentale L.) Sebagai Antibakteri Terhadap Salmonella typhimurium
}

\author{
Adi Rianto1,2, Muhammad Isrul1 ${ }^{1}$, Sri Anggarini ${ }^{3}$, Ahmad Saleh ${ }^{1}$ \\ ${ }^{1}$ Program Studi Farmasi STIKES Mandala Waluya Kendari \\ ${ }^{2}$ Akademi Bina Husada Kendari \\ 3Program Studi Analis Kesehatan STIKES Mandala Waluya Kendari
}

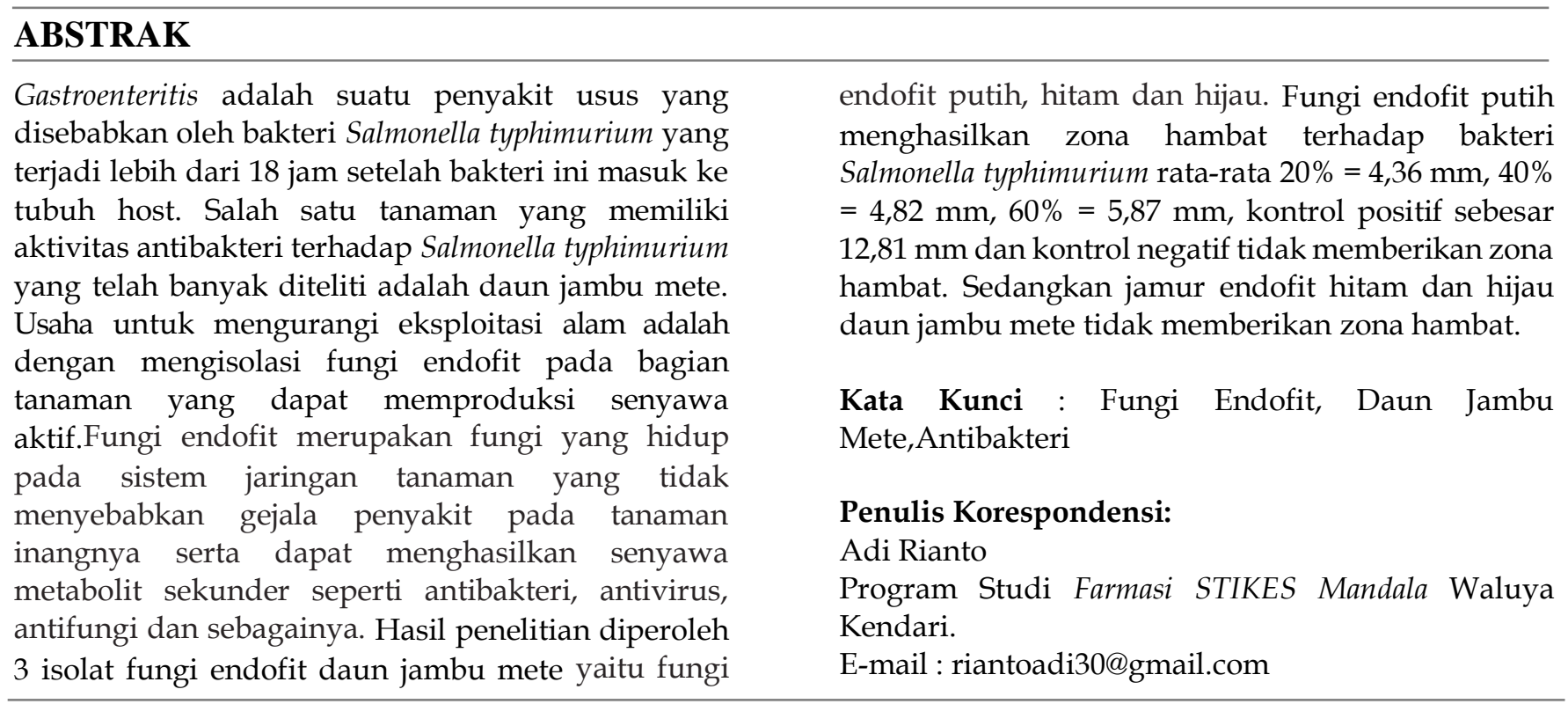

\section{PENDAHULUAN}

Penyakit gastroenteritis masih menjadi masalah kesehatan bagi masyarakat di negara berkembang seperti Indonesia. Di Indonesia diperkirakan penderita diare sekitar 60 juta keadaan setiap tahunnya, sebagian besar (70-80\%) dari penderita ini adalah anak-anak dibawah umur 5 tahun (Suraatmaja, 2007).

Gastroenteritis adalah suatu penyakit usus yang disebabkan oleh bakteri Salmonella typhimurium yang terjadi lebih dari 18 jam setelah bakteri ini masuk ke tubuh host (penjamu). Gejala klinis gastroenteritis adalah demam, muntah, sakit kepala, diare, dan sakit pada abdomen (abdominal pain) yang terjadi selama 2-5 hari (Prihandani, 2015). Salmonella typhimurium digolongkan dalam Enterobacteria Tribe III yang merupakan bakteri parasit pada hewan dan manusia. Bakteri ini bersifat patogen pada manusia, habitat bakteri Salmonella typhimurium adalah didalam alat 
pencernaan manusia, hewan, dan bangsa burung. Oleh karena itu cara penularannya melalui makan dan minum yang masuk kedalam alat pencernaan manusia, dimana sudah tercemar oleh bakteri Salmonella typhimurium (Dharmojono, 2001).

Pertolongan pertama yang dapat dilakukan untuk penyakit gastroenteritis yaitu dengan menggunakan bahan alam, salah satunya yaitu pemanfaatan Jambu mete yang mengandung senyawa kimia seperti tanin, anacardic acid dan cardol, yang bermanfaat sebagai antibakteri dan antiseptik (Herbie, 2015). Daun jambu mete memiliki banyak manfaat bagi kesehatan, sehingga masyarakat indonesia banyak memanfaatkanya sebagai obat herbal sejak zaman dahulu. Air rebusan daun muda jambu mete dikonsumsi sebagai obat untuk tekanan darah tinggi (hipertensi), kencing manis (diabetes militus), malaria, rematik, sariawan dan ruam kulit. Daun tua jambu mete dimanfaatkan sebagai obat untuk luka bakar, antidiabetes dan obat sakit perut. Di dunia farmakologi infusa daun muda jambu mete diketahui memiliki efek antifungi dan antibakteri (Dalimartha, 2006)

Berdasarkan penelitian yang telah dilakukan oleh Melati Puspita Sari (2013), dikatakan bahwa ekstrak etanol $70 \%$ daun jambu mete dengan konsentrasi $2 \%$ mempunyai efek antibakteri terhadap Salmonella typhimurium.

Agar dapat meningkatkan pengembangan budidaya dan produksi tanaman obat maka diperlukan berbagai usaha penelitian terhadap tanaman obat yang tumbuh di Indonesia agar mengurangi eksploitasi alam. Karena telah banyak terjadi eksploitasi bagian tanaman sebagai tanaman obat yang terus meningkat menyebabkan semakin berkurangnya sumber daya alam. Salah satu usaha untuk mengurangi eksploitasi tersebut adalah dengan mengisolasi jamur endofit pada bagian tanaman yang dapat memproduksi senyawa aktif. Beberapa mikroba endofit dapat terkandung oleh setiap tanaman tingkat tinggi, yang dapat menghasilkan senyawa metabolit sekunder atau senyawa biologi yang diduga merupakan akibat dari koevolusi atau transfer genetik oleh tanaman inang ke dalam mikroba endofit (Tan Rx., dkk. 2001). Jambu mete merupakan tanaman tingkat tinggi dimana tumbuhan tersebut sudah memiliki struktur batang, akar, dan daun sejati, yang dapat menghasilkan fungi endofit. Fungi endofit merupakan fungi yang hidup didalam jaringan tumbuhan tanpa menimbulkan gejala penyakit pada tumbuhan inangnya. Fungi endofit mampu menghasilkan senyawa bioaktif misalnya senyawa antibakteri, antifungi, antivirus, antikanker, antimalaria dan sebagainya (Prihatiningtias., $d k k, 2011)$. Fungi endofit yang tumbuh pada jaringan tumbuhan obat dapat memiliki jenis senyawa yang sama atau berbeda yang tumbuhan inangnya namun memiliki khasiat aktivitas yang sama. Bahkan, tidak jarang ditemukan bahwa senyawa yang dihasilkan fungi endofit mempunyai aktivitas yang lebih besar daripada aktivitas tumbuhan inangnya. (Prihatiningtias, 2005). Dari latar belakang diatas, penulis tertarik mengambil judul "Isolasi dan Identifikasi 
Jamur Endofit daun Jambu Mete (Anacardium occidentale L.) Sebagai Antibakteri Terhadap Salmonella typhimurium".

\section{METODE PENELITIAN}

Jenis penelitian yang digunakan adalah penelitian eksperimen. Eksperimen merupakan suatu penelitian dengan melakukan kegiatan percobaan yang bertujuan untuk mengetahui gejala atau pengaruh yang timbul, sebagai akibat dari adanya perlakuan tertentu atau eksperimen tersebut (Notoatmodjo, S. 2012).

Alat

Autoklaf (Mammert), Batang pengaduk, Cawan petri, Gelas kimia (Pyrex), Gelas ukur (Pyrex), Inkubator (Yenaco), Jangka sorong, Jarum ose, LAF (laminar air flow), Lampu spiritus, Magnetic stirrer (HMS-79), Mikroskop, Mikropipet, Oven (Yenaco), Pingset, Centifuge (80-1), Shaker incubator (Health), Tabung reaksi (Pyrex) dan Timbangan analitik.

Bahan

Aquadest, Etanol 70\%, Kloramfenikol ${ }^{\circledR}$, Larutan $\mathrm{NaCl}$ 0,9\%, media PDA (Potato Dextrose Agar) (Oxoid) ${ }^{\circledR}$, Media PDY (Potato Dextrose Yeast) $(\text { Oxoid })^{\circledR}$ media NA (Nutrient Agar)(Pronadisa) ${ }^{\circledR}, \quad \mathrm{NaOCl}$ $5,25 \%$, Salmonella typhimurium dan Daun Jambu Mete.

Prosedur Kerja Pembuatan Media Potato Dextrose Agar (PDA)

Pembuatan media Potato Dextrose Agar (PDA) dilakukan dengan cara menimbang media Potato Dextrose Agar (PDA) sebanyak 14,04 gram dilarutkan dengan $360 \mathrm{~mL}$ aquades $(39 \mathrm{~g} / 1000 \mathrm{~mL}$ ) dalam Erlenmeyer. Kemudian, dipanaskan menggunakan hot magnetic strirer hingga mendidih dan diperoleh larutan jernih. Disterilkan dalam autoklaf dengan suhu $121^{\circ} \mathrm{C}$ selama 15 menit (Arleine., dkk, 2017).

\section{Pembuatan Media Nutrient Agar (NA)}

Pembuatan media Nutrient agar (NA) dilakukan dengan cara menimbang media Nutrient agar (NA) sebanyak 2,8 gram dilarutkan dalam $100 \mathrm{~mL}$ aquadest (28 $\mathrm{g} / 1000 \mathrm{~mL}$ ) menggunakan erlenmeyer. Setelah itu dipanaskan dengan hot magnetic stirrer sampai mendidih dan diperoleh larutan jernih. Kemudian, disterilkan dalam autoklaf pada suhu $121^{\circ} \mathrm{C}$ selama 15 menit (Arleine., dkk, 2017).

\section{Isolasi Jamur Endofit}

Daun jambu mete (Anacardium occidentale L.) dibersihkan dengan cara dicuci dengan air mengalir untuk menghilangkan sisa tanah dan kotoran yang menempel. Daun dipotong hingga ukurannya menjadi $2 \mathrm{~cm}$, kemudian dikeringkan di atas cawan petri. Sampel dimasukkan e dalam erlenmeyer $250 \mathrm{~mL}$, lalu ditambahkan pelarut etanol $70 \%$ hingga sampel terendam. Dikocok pelan, kemudian disterilisasi selama 2 menit. Setelah 2 menit, pelarut etanol $70 \%$ dibuang, lalu sterilisasi dilanjutkan kembali dengan ( $\mathrm{NaOCl} 5,25 \%)$ selama 2 menit. Dibilas dengan aqua pro injesi selama 1 menit, dilakukan sebanyak 3 kali. Sterilisasi dilakukan menggunakan autoklaf, lalu dimasukkan ke dalam cawan petri steril. Bagian tersebut ditanam pada media Potato Dextrose Agar didiamkan selama 3 hari dengan suhu kamar $\left(25^{\circ} \mathrm{C}\right)$. Air bilasan terakhir diinokulasikan pada 
medium Potato Dextrose Agar (PDA), sebagai kontrol. Setelah 3 hari terjadi pertumbuhan fungi, kemudian diisolasi untuk mendapat morfologi endofit murni ( Azdar., dkk, 2016)

\section{Seleksi Fungi Endofit Penghasil}

\section{Antibakteri}

Fungi endofit yang telah tumbuh pada media isolasi kemudian dimurnikan ke dalam media Potato Dextrose Agar (PDA) plate lain. Koloni yang mempunyai bentuk yang berbeda dengan koloni lainnya dapat dianggap sebagai isolate yang berbeda. Kemudian dilakukan pemurnian sampai diperoleh isolate murni (tunggal). Pemurnian dilakukan dengan cara menginokulasikan sedikit hifa dengan ose atau pinset dari setiap koloni endofit yang berbeda ke media Potato Dextrose Agar (PDA) dan diunkubasi selama 7 hari pada suhu ruang (kumala et al., 2006). Selanjutnya isolate Fungi yang telah murni dipindahkan ke dalam media Potato Dextrose Agar (PDA) lain untuk digunakan sebagai working culture dan media agar miring Potato Dextrose Agar (PDA) yang digunakan sebagai stock culture. Kultur Fungi endofit diinkubasi selama 7 hari pada suhu ruang (kumala dan Endro, 2007)

Pembuatan Metabolit Sekunder Antibakteri Fungi Endofit Daun Jambu Mete (Anacardium occidentale L.).

Fungi endofit difermentasi menggunakan media Potato Dextrose Yeast (PDY), diambil masing-masing koloni fungi endofit dengan menggunakan ose bulat berukuran $1 \times 1 \mathrm{~cm}$, selanjutnya diinokulasikan ke dalam media Potato
Dextrose Yeast (PDY) sebanyak $100 \mathrm{~mL}$ dalam gelas Erlenmeyer. Dishaker media fermentasi selama 14 hari, kemudian dimasukkan ke dalam tabung sentrifus yang berukuran $15 \mathrm{~mL}$, disentrifugasi selama 30 menit dengan kecepatan 3000 rpm, hasil dalam bentuk supernatant (metabolit sekunder) kemudian diambil untuk dibuat pengenceran 20\%, 40\% dan 60\% (Azdar., dkk, 2016).

\section{Pembuatan Pengenceran Metabolit}

Sekunder Fungi Endofit Daun Jambu

Mete (Anacardium occidentale L.).

Pengenceran fungi endofit daun jambu mete untuk 20\% Dipipet $2 \mathrm{~mL}, 40 \%$ dipipet $4 \mathrm{~mL}$ dan $60 \%$ dipipet $6 \mathrm{~mL}$ supernatan kedalam tabung reaksi. Tambahkan masing-masing aquadest steril hingga $10 \mathrm{~mL}$. Aduk hingga homogen, dan diberi label.

Pengujian Diameter Zona Hambatan Metabolit Sekunder Fungi Endofit Daun Jambu Mete (Anacardium occidentale L.). Terhadap Pertumbuhan Bakteri Salmonella typhimurium dengan Metode Sumuran agar.

Disiapkan sampel pengenceran fungi endofit daun jambu mete $20 \%, 40 \%$ dan $60 \%$, serta kontrol positif dan kontrol negatif, Suspensi bakteri Salmonella typhimurium dimasukkan ke dalam media kombinasi (PDA+NA). Di pipet $20 \mathrm{~mL}$ inokulum ke dalam cawan petri, tunggu sampai memadat. Dibuat sumuran pada permukaan agar. Dimasukkan masingmasing pengenceran fungi endofit daun jambu mete kedalam sumuran agar yang telah dibuat. Inkubasi pada suhu $25^{\circ} \mathrm{C}$ 
selama $1 \times 24$ jam, selanjutnya amati dan ukur zona hambat dari masing-masing sampel pengenceran tersebut (Azdar., dkk, 2016)

\section{HASIL DAN PEMBAHASAN}

\section{Hasil}

Isolat yang didapatkan setelah isolasi fungi endofit dari daun jambu mete, dilakukan pemurnian berdasarkan warna koloni pada medium PDA (Potato Dextrose Agar). Hasil yang diperoleh dari pemurnian dapat dilihat dari bentuk yang tampak secara makroskopik dan diperoleh 3 macam fungi endofit, isolat tersebut dapat dilihat pada tabel 3. beserta ciri makroskopisnya pada tabel 3. sebagai berikut:

Tabel 3. Data Hasil isolasi fungi endofit pada daun jambu mete

\begin{tabular}{ccl} 
Jumlah Isolat Warna Permukaan & \multicolumn{1}{c}{ Bentuk Koloni } \\
\hline 1 & Putih & $\begin{array}{l}\text { putih seperti kapas dan terlihat } \\
\text { seperti serabut halus }\end{array}$ \\
\hline 1 & Hitam & $\begin{array}{l}\text { koloni berbentuk bulat, } \\
\text { pertumbuhan koloni menyebar dan } \\
\text { tebal }\end{array}$ \\
\hline 1 & Hijau & $\begin{array}{l}\text { koloni berbentuk bulat, } \\
\text { pertumbuhan koloni menyebar dan } \\
\text { tebal }\end{array}$ \\
\hline
\end{tabular}

Tabel 4. Data Hasil Penelitian Fungi Endofit Putih

\begin{tabular}{|c|c|c|c|c|c|}
\hline \multirow[t]{2}{*}{ Perlakuan } & \multicolumn{3}{|c|}{$\begin{array}{l}\text { Hasil zona hambat (mm) terhadap } \\
\text { bakteri Salmonella typhimurium }\end{array}$} & \multirow{2}{*}{$\begin{array}{l}\text { otal } \\
\text { mm) }\end{array}$} & \multirow{2}{*}{$\begin{array}{l}\text { Rata-rata } \\
\mathrm{mm}) \pm \mathrm{SD}\end{array}$} \\
\hline & $\begin{array}{c}\mathrm{I} \\
(\mathrm{mm})\end{array}$ & $\begin{array}{c}\text { II } \\
(\mathrm{mm})\end{array}$ & $\begin{array}{c}\text { III } \\
(\mathrm{mm})\end{array}$ & & \\
\hline Konsentrasi 20\% & 4,38 & 4,32 & 4,38 & $.3,08$ & $36 \pm 0,03464$ \\
\hline Konsentrasi 40\% & 4,78 & 4,90 & 4,77 & 4,45 & $82 \pm 0,07234$ \\
\hline Konsentrasi 60\% & 5,85 & 5,88 & 5,88 & 7,61 & $87 \pm 0,01732$ \\
\hline $\begin{array}{l}\text { Khloramphenikol } \\
\circledast{ }^{\circ}\end{array}$ & 13,45 & 13,10 & 11,87 & $: 8,42$ & $81 \pm 0,82984$ \\
\hline Aquadest & 0 & 0 & 0 & 0 & 0 \\
\hline
\end{tabular}


Tabel 5. Data Hasil Penelitian Fungi Endofit Hitam

\begin{tabular}{lccccc}
\hline Perlakuan & \multicolumn{2}{c}{$\begin{array}{c}\text { Hasil zona hambat (mm) terhadap bakteri } \\
\text { Salmonella typhimurium }\end{array}$} & $\begin{array}{c}\text { Total } \\
\mathbf{m m})\end{array}$ & $\begin{array}{c}\text { Rata-rata } \\
\text { (mm) } \pm \text { SD }\end{array}$ \\
& $\begin{array}{c}\text { I } \\
(\mathbf{m m})\end{array}$ & $\begin{array}{c}\text { II } \\
(\mathbf{m m})\end{array}$ & $\begin{array}{c}\text { III } \\
(\mathbf{m m})\end{array}$ & 0 & 0 \\
\hline Konsentrasi 20\% & 0 & 0 & 0 & 0 & 0 \\
\hline Konsentrasi 40\% & 0 & 0 & 0 & 0 & 0 \\
\hline Konsentrasi 60\% & 0 & 0 & 0 & 39,63 & $13,21 \pm 0,00816$ \\
\hline Khloramphenikol ${ }^{\circledR}$ & 13,20 & 13,22 & 13,21 & 0 & 0 \\
\hline Aquadest & 0 & 0 & 0 & & 0 \\
\hline
\end{tabular}

Tabel 6. Data Hasil Penelitian Fungi Endofit Hijau

\begin{tabular}{|c|c|c|c|c|c|}
\hline \multirow{3}{*}{ Perlakuan } & \multicolumn{4}{|c|}{;il zona hambat $(\mathrm{mm})$ terhadap bakteri } & \multirow{3}{*}{$\begin{array}{l}\text { Rata-rata } \\
(\mathrm{mm}) \pm \mathrm{SD}\end{array}$} \\
\hline & \multirow[b]{2}{*}{$\begin{array}{c}\mathrm{I} \\
(\mathrm{mm})\end{array}$} & \multicolumn{2}{|c|}{ Salmonella typhimurium } & \multirow{2}{*}{$\begin{array}{l}\text { 'otal } \\
\mathrm{mm})\end{array}$} & \\
\hline & & $\begin{array}{c}\text { II } \\
(\mathrm{mm})\end{array}$ & $\begin{array}{c}\text { III } \\
(\mathrm{mm})\end{array}$ & & \\
\hline Konsentrasi 20\% & 0 & 0 & 0 & 0 & 0 \\
\hline Konsentrasi 40\% & 0 & 0 & 0 & 0 & 0 \\
\hline Konsentrasi $60 \%$ & 0 & 0 & 0 & 0 & 0 \\
\hline 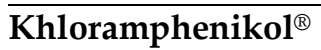 & 13,25 & 13,27 & 13,25 & 9,77 & $26 \pm 0,00942$ \\
\hline Aquadest & 0 & 0 & 0 & 0 & 0 \\
\hline
\end{tabular}

\section{Pembahasan}

Telah dilakukan uji isolasi dan identifikasi fungi endofit daun jambu mete terhadap pertumbuhan bakteri Salmonella typhimurium. Pengambilan daun jambu mete dilakukan secara langsung (pemetikan) pada pukul 08.0009.00. Pada saat puncak fotosintesis, tanaman mengalami proses metabolisme yang optimal sehingga menghasilkan metabolit yang lebih banyak (Prihatiningtias, W. 2005). Penyiapan daun jambu mete yang dibutuhkan dicuci bersih dengan air mengalir, agar semua kotorannya hilang. 
Isolasi fungi indofit dari bagian tanaman yang berbeda atau dari tanaman yang berbeda tetapi dari satu tumbuhan inang akan memiliki jenis isolat jamur yang berbeda. Isolasi fungi endofit dilakukan sterilisasi permukaan sampel terlebih dahulu sebelum ditanamkan pada medium. Sterilisasi permukaan sampel dilakukan dengan cara merendam sampel dalam pelarut alkohol 70\%, kemudian $\mathrm{NaOCl} \mathrm{5,25 \%}$ dan terakhir dibilas dengan aquadest steril agar cairan $\mathrm{NaOCl}$ yang masih menempel pada daun jambu mete dapat hilang. Penggunaan etanol $70 \%$ dan $\mathrm{NaOCl} 5,25 \%$ karena dengan konsentrasi tersebut efektif menghambat pertumbuhan bakteri (Yan dkk, 2010).

Proses sterilisasi permukaan dilakukan untuk menjamin sterilitas permukaan sampel dari kontaminasi organisme. Sampel yang telah disterilisasi permukaannya kemudian dipotong-potong daun jambu mete $1 \times 1$ $\mathrm{cm}$ agar lebih mudah untuk ditanam ke medium karena ukurannya yang lebih kecil, lalu ditempelkan pada medium yang telah memadat. Medium yang digunakan saat isolasi yaitu medium PDA (Potato Dextrose Agar), karena medium ini berisi nutrisi yang dibutuhkan oleh fungi. Lalu ditambahkan kloramfenikol PDAC (Potato Dextrose Agar Chloramphenicol), hal ini dilakukan untuk menekan pertumbuhan bakteri yang kemungkinan ikut tumbuh saat isolasi.
Kemudian diinkubasi selama 14 hari, agar fungi endofit yang tumbuh lebih banyak.

Setelah 14 hari fungi endofit yang tumbuh disekeliling daun jambu mete dimurnikan (dipisahkan) hingga memperoleh isolat fungi endofit. Hal ini dilakukan agar tidak mempengaruhi hasil penghambatan dan pengamatan di mikroskop. Pemisahan ini berdasarkan warna dan pola pertumbuhan koloni fungi. Fungi endofit dipindahkan kembali dalam medium PDAC (Potato Dextrose Agar Chloramphenicol) yang baru, dimana yang akan diisolasi yaitu fungi dengan koloni berwarna putih, hijau dan berwarna hitam. Fungi endofit yang didapatkan hanya 3 jenis yaitu fungi endofit hitam, putih dan hijau. Keberadaan fungi endofit bersifat acak dan dapat berada dimana-mana. Hal ini sesuai dengan pernyataan Atmosukarto (2006) karena tumbuh didalam jaringan tanaman, dimana tanaman yang satu tentunya berbeda dengan tanaman lainnya, maka biotop (habitat) tempat hidup mikroba yang sangat unik sifatnya. Bahkan fisiologi tumbuhan tingkat tinggi termasuk yang berasal dari spesies yang sama akan berbeda di lingkungan yang berbeda.

Isolat fungi endofit dari daun jambu mete yang telah murni selanjutnya dikarakterisasi untuk melihat ciri-ciri jamur secara makroskopik. hasil isolasi fungi endofit dari daun jambu mete (Pluchea indica (L.) 
Less.) diperoleh tiga isolat fungi endofit yaitu isolat fungi endofit putih, hitam dan hijau. Pengamatan makroskopik pada isolat fungi endofit putih yang tumbuh pada medium PDA (Potato Dextrose Agar) koloni berwarna putih seperti kapas dan terlihat seperti serabut halus sedangkan isolat fungi endofit hitam dan hijau koloni berbentuk bulat, pertumbuhan koloni menyebar dan tebal.

Setelah dipisahkan antara fungi endofit putih, fungi endofit hitam dan fungi endofit hijau, kemudian dilakukan proses fermentasi. Fermentasi dilakukan untuk memperoleh senyawa metabolit sekunder dari isolat fungi endofit. Media yang digunakan adalah media cair PDY (Potato Dextrose Yeast). Media PDY (Potato Dextrose Yeast) digunakan karena mengandung nutrisi yang dibutuhkan oleh fungi endofit. Fermentasi fungi endofit digunakan media cair karena fermentasi menggunakan media cair lebih efektif dalam memproduksi biomassa (Pokhrel and Ohga, 2007) dan senyawa bioaktif bila dibandingkan dengan fermentasi menggunakan media padat (Yan dkk, 2010). Hal ini disebabkan dalam fermentasi media cair terdapat proses agitasi (pengadukan) yang memungkinkan nutrisi dalam media dapat terus homogen dan tidak ada gradient konsentrasi produk/toksin sehingga fungi endofit dapat lebih optimal mengabsorbsi nutrisi tersebut. fungi endofit yang difermentasi di dalam media cair PDY (Potato Dextrose Agar) diaduk menggunakan shaker incubator selama 14 hari bertujuan agar media tersebar merata sehingga fungi endofit mendapatkan nutrisi yang cukup, dan waktu 14 hari diharapkan fungi endofit lebih banyak memproduksi metabolit sekunder. Kemudian disentrifugasi agar endapan (pelet) dan supernatannya terpisah. Setelah terpisah supernatan ini yang akan digunakan dalam pengujian daya hambat, karena supernatan mengandung senyawa metabolit sekunder.

Pengujian daya hambat fungi endofit ini digunakan adalah supernatannya, pengenceran supernatan yang diambil yaitu $20 \%, 40 \%$ dan $60 \%$ serta kontrol positif yang

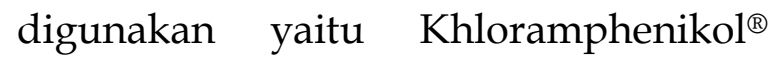
0,1\% dan kontrol negatifnya aquadest steril. Digunakan Khloramphenikol 0,1\% sebagai kontrol positif karena merupakan Obat antibiotik yang mempunyai spektrum kerja yang luas. Suspensi bakteri uji Salmonella typhimurium, dimasukkan kedalam cawan petri yang telah berisi media kombinasi (PDA + NA), media dikombinasikan karena sampel yang digunakan fungi endofit beserta bakteri uji Salmonella typhimurium. Dimasukan masing-masing sampel pengenceran fungi endofit daun jambu mete $20 \%, 40 \%$ dan $60 \%$ Serta larutan kontrol positif dan kontrol negatif kedalam sumuran agar yang telah berisi media kombinasi (PDA 
+ NA) dan bakteri uji Salmonella typhimurium. Selanjutnya diinkubasi pada suhu kamar $\left(37^{\circ} \mathrm{C}\right.$ selama $1 \times 24$ jam). Diinkubasi pada suhu dan waktu tersebut karena merupakan suhu yang optimal untuk pertumbuhan bakteri serta bakteri sudah dapat tumbuh pada waktu 1×24 jam. Kemudian zona hambat dari fungi endofit daun jambu mete diamati dan diukur menggunakan jangka sorong.

Berdasarkan Tabel 4 isolat fungi endofit putih dari daun jambu mete mampu menghambat pertumbuhan bakteri uji Salmonella typhimurium sehingga dapat dikatakan fungi endofit putih dari daun jambu mete mampu menghasilkan metabolit sekunder yang berfungsi sebagai antibakteri. Hal ini sesuai dengan penelitian sebelumnya oleh Strobel, 2003 dalam Prihatiningtias dkk, 2011 menyatakan fungi endofit mampu menghasilkan senyawa-senyawa bioaktif misalnya senyawa antibakteri, antifungi, antivirus, antikanker, antimalaria dan sebagainya. Alasan pemilihan fungi endofit dibanding bakteri endofit adalah hal ini dilihat dari struktur selnya, fungi adalah mikroorganisme yang paling dekat dengan tumbuhan. (Agusta, 2009).

Fungi endofit putih memiliki daya hambat rata-rata pada konsentrasi $20 \%$ yaitu $4,36 \mathrm{~mm}, 40 \%$ yaitu $4,82 \mathrm{~mm}$ dan konsentrasi $\quad 60 \%$ yaitu $5,87 \quad \mathrm{~mm}$ sedangkan kontrol positifnya $12,81 \mathrm{~mm}$. Menurut (Pan, dkk 2009) konsentrasi
$20 \%, 40 \%$ dan $60 \%$ masih termasuk daya hambat dalam kategori sedang karena < $6 \mathrm{~mm}$. Dari hasil rata-rata zona hambat kontrol positif memiliki zona hambatan yang besar dan termasuk dalam kategori kuat karena $>6 \mathrm{~mm}$, hal ini berbeda dengan rata-rata zona hambat dari fungi endofit yang dikategorikan sedang, artinya sampel belum bisa digunakan sebagai pengganti antibiotik yang beredar di pasaran.

Fungi endofit putih memiliki daya hambat karena menurut (Tan RX., dkk, 2001 dalam Radji, M. 2005), Beberapa mikroba endofit yang mampu menghasilkan senyawa biologi atau metabolit sekunder yang diduga sebagai akibat koevaluasi atau transfer genetik (genetic recombination) dari tanaman inangnya kedalam mikroba endofit, dimana menurut (Herbie, 2015) jambu mete yang mengandung senyawa kimia seperti tanin, anacardic acid dan cardol, yang bermanfaat sebagai antibakteri dan antiseptik.

Mekanisme aktivitas antibakteri dari fenolat yang disebut juga asam karbolat dapat menyebabkan denaturasi protein melalui proses adsorpsi yang melibatkan ikatan hidrogen. Pada kadar rendah, terbentukalah kompleks proteinfenol dengan ikatan lemah dan segera mengalami penguraian, diikuti penetrasi fenol kedalam sel dan menyebabkan presipitasi serta denaturasi protein. Pada kadar tinggi, fenol menyebabkan koagulasi protein dan sel membran 
mengalami lisis, mengubah permeabilitas membran bakteri (Siswandono dan Soekardjo, 2000). Sedangkan Mekanisme aktivitas antibakteri chlorhexidine gluconate adalah dengan cara merusak dinding sel bakteri, menghambat sistem enzimatik dan mengeluarkan lipopolisakarida dari dinding sel bakteri yang mengakibatkan kematian sel bakteri (Kuyyakanond \& Quenel, 1992; Mandel, 1994) Sedangkan berdasarkan tabel 5 dan 6 fungi endofit hitam dan hijau tidak mempunyai daya hambat, hal ini diduga karena metabolit sekunder yang dihasilkan oleh fungi endofit hitam dan hijau tidak sebanyak fungi endofit putih yang dapat menghambat bakteri Salmonella typhimurium.

Dari data pengujian statistik ANOVA dapat disimpulkan bahwa supernatan fungi endofit daun jambu mete memiliki nilai signifikan 0,000 $(<0,05)$ memiliki daya antibakteri terhadap pertumbuhan bakteri Salmonella typhimurium.. Berdasarkan hasil pengujian Ho ditolak dan $\mathrm{Ha}$ diterima atau dengan kata lain nilai $\mathrm{F}$ hitung lebih besar dibandingkan dengan F total. Uji One Way ANOVA merupakan uji yang digunakan untuk melihat ada tidaknya pengaruh pada setiap kelompok, tetapi tidak dapat digunakan untuk melihat seberapa besar signifikansi perbedaan rata-rata daya hambat tiap kelompok perlakuan sehingga dilakukan uji selanjutnya yaitu uji Post Hoc Test Turkey. Perbedaan rata-rata tiap kelompok perlakuan pada penelitian ini diuji dengan Uji Post Hoc Test Turkey. Hasil yang didapatkan menunjukkan bahwa masing-masing perlakuan mempunyai perbedaan daya hambat antibakteri yang signifikan. Dari hasil analisis Post Hoc Test Turkey bahwa semua konsentrasi fungi endofit $20 \%, 40 \%$ dan $60 \%$ menunjukkan perbedaan signifikan dengan kontrol negatif, hal ini berarti bahwa semua konsentrasi memiliki aktivitas sebagai antibakteri. Jika dibandingkan dengan kontrol positif semua konsentrasi fungi endofit memperlihatkan perbedaan yang signifikan, hal ini menunjukkan bahwa semua konsentrasi fungi endofit memiliki aktivitas antibakteri yang kurang baik dari kontrol positif.

\section{KESIMPULAN}

Berdasarkan hasil penelitian yang telah dilakukan diperoleh kesimpulan sebagai berikut :

1. Ditemukan fungi endofit pada daun Jambu Mete (Anacardium occidentale L.)

2. Hasil uji supernatan fungi endofit putih, memperlihatkan bahwa dapat menghambat pertumbuhan bakteri Salmonella typhimurium Sedangkan isolat fungi endofit hitam dan hijau tidak dapat menghambat pertumbuhan bakteri Salmonella typhimurium. 


\section{UCAPAN TERIMA KASIH}

Ungkapan terima kasih juga tidak lupa penulis sampaikan kepada Muhammad Isrul, S.Si., M.Si., Apt dan kepada Sri Anggarini R, S.Si., M.Si atas semua waktu, tenaga dan pikiran yang telah diberikan dalam membimbing, mengarahkan, memberi saran maupun kritik sehingga hasil penelitian ini menjadi lebih baik.

\section{DAFTAR PUSTAKA}

Abulude, Ogunkoya, \& Adebote, 2009, Phytochemical And Antibacterial Investigation of Crude Extracts of Leaves And Stem Barks Of Anacardium Occidentale, Continental J. Biological Sciences 2, 12 -16.

Arleine R. I. Tangkuman., dkk. 2017. Uji Aktivitas Antibakteri Ekstrak Etanol Kulit Batang Jambu Mete (Annacardium occidentale L.) Dalam Menghambat Pertumbuhan Bakteri Dari Air Liur Penderita Sariawan. Pharmacon Jurnal Ilmiah Farmasi, UNSRAT.

Azdar, M, Setiawan., dkk. 2016. Uji Daya Hambat Antibakteri Fungi Endofit Kulit Jeruk Nipis (Citrus aurantifolia) Terhadap Bakteri Staphylococcus aureus. Jurnal Sains Farmasi \& Klinis, IAI Sumatera Barat.

Castillo, U.F., Strobel, G.A., Ford, E.J., Hess, W.M ., Poter, H., Jenson, J.B., dkk, 2002, Munumbicins, Wide Spectrum Antibiotics Produced By Streptomyces NRRL 30562, Endophytic On Kennedia Nigriscans. Microbiology, 148:2675-2685.

Castillo, U.J., Harper, K.., Strobel, G.A., Sears, J., Alesi, K., Ford, E., dkk,
2003,Kakandumycins, Novel Antibiotics From Streptomyces Sp. NRRL30566, anEndo - Phyteof Grevillea Pteridifolia. FEMS Lett, 24:183-190.

Dalimartha,S., 2001, Atlas Tumbuhan Obat Indonesia, Jilid 2, 80, Pustaka Bunda, Jakarta.

Dalimartha,S., 2006, Atlas Tumbuhan Obat Indonesia, Jilid 2, Trubus Agriwidya, Jakarta.

Deby. A. Mpilah., dkk. 2012. Uji Aktivitas Antibakteri Ekstrak Etanol Daun Mayana (Coleus atropurpureus [L] Benth) Terhadap Staphylococcus aureus, Escherichia coli dan Pseudomonas aeruginosa Secara INVITRO. Jurnal Penelitian, UNSRAT.

Dharmojono. 2001. Lima belas Penyakit Menular dari Binatang ke Manusia. Milenia Populer, Jakarta.

Gunawan, S.G(ed). 2007, Farmakologi dan Terapi, edisi 5, UI Press, Jakarta.

Guo, B.,Dai, J.,Ng, S.,Huang, Y.,Leong, C., Ong,W., dkk, 2000, Cytonicacid A and $B$, novel tridepsid einhibitor of CMV protease from the endophytic fungus Cytonaena sp. J. Nat. Prod, 63:602-604.

Herbie, T. 2015. Kitab Tanaman Berkhsiat Obat. Octopus, Yogyakarta.

Harrison,L., Teplow, C., Rinaldi, M., and Strobel,G.A. dkk, 1991, Pseudomycins, afamily of novel peptides from Pseudomonas Syringae, possessing broad spectrum antifungal activity. J. Gen. Microbiol. 137:2857-2865.

Horn WS.,Simmonds M.S.J.,Schartz, RE., and Blaney, W.M. dkk. 1995, Phomopsichalasin, anovelantimi crobial agent from an endophytic 
Phomopsis Spp. Tetrahedron, 14:3969-3978.

Jay, J.M, 2000. Modern Food Microbiology, 6th. Ed. Aspen Publisher, Inc., Maryland. Jawetz, E., J.L. Melnick, and E.A. Adelberg, 2001. Mikrobiologi untuk Profesi Kesehatan (Review of Medical Mikrobiology) Diterjemahkam oleh $H$. Tomang. Jakarta.

Jawetz, E., Melnick, J.L. \& Adelberg, E.A, 2005. Mikrobiologi Kedokteran, diterjemahkan oleh Bagian Mikrobiologi Fakultas Kedokteran Universitas Airlangga, 233-235 \& 363-364. Jakarta: Salemba Medika.

Kumala S., dkk, 2006, Aktivitas Metabolit Bioaktif Mikroba Endofitik Tanaman Trengguli (Cassia fistula L). jurnal farmasi Indonesia 3(2) : 97102

LPPM IPB, Pusat Studi Biofarmaka dan Gagas Ulung, 2014. Sehat Alami Dengan Herbal 250 Tanaman Herbal Berkhasiat Obat +60 Resep Menu Kesehatan. PT. Gramedia Pustaka Utama, Jakarta. Lay, b.w., and s. Hastowo, 1992. Mikrobiologi. Rajawali Press, Jakarta.

Lee, J. Lobkovsky, E., Pliam N.B., Strobel, G.A., and $\mathrm{Cl}$ ardy,J., dkk, 1995, Subglutinols $A$ and $B$ : immuno suppressive compounds from the endophytic fungus Fusarium subglutinans. J. Org. Chem, 60:70767077.

LiJ.Y., Harper, J.K., Grant, D.M., Tombe, B.O., Basyal, B., Hess, W.M., dkk, AmbuicAcid, a Highly Functionalized Cyclohexen one With Antifungal Activity From Pestalotiopsis Spp.
And Monochaetia Spp. Pytochemistry, 56:463-468.

Lucky dkk, 1994. Batang Negatif Gram. Dalam: Syahrurachman et al. Buku Ajar Mikrobiologi kedokteran Edisi Revisi. Jakarta: Binarupa Aksara

Mycek dkk, 2001, Farmakologi Ulasan Bergambar edisi 2, Penerbit Widya Medika, Jakarta

Miller, RV., Miller, C.M., Garton-Kinney, D., Redgrave, B., J. Sears, Condron, M. dkk, 1998, Ecomycins, unique antimycotics from Pseudomonas virid flava. J. Appl. Microbiol. 84:937-944.

Notoatmodjo, S. 2012, Metodologi Penelitian Kesehatan, Rineka Cipta, Jakarta.

Pan, X., Chen, F., Wu, T., Tang, H., and Zhao, Z. 2009. The acid, Bile Tolerance and Antimicrobial property of Lactobacillus acidophilus NIT. J. Food Kontrol 20 : 598-602

Prihandani, S,S,. Poeloengan, M,. Noor, S,M,. Andriani, 2015. "Uji daya Antibakteri Bawang Putih (Allium sativum 1.) Terhadap Bakteri Staphylococcus aureus, Escherichia coli, Salmonella typhimurium dan Pseudomonas aeruginosa dalam meningkatkan Keamanan Pangan". Jurnal. Bogor. 53-58.

Prihatiningtias,W. 2005. Senyawa Bioaktif Fungi Endofit Tumbuhan Akar Kuning (Fibraurea chloroleuca Miers) Sebagai Agensia Antimikroba. Tesis. Program Studi Bioteknologi, Sekolah Pascasarjana UGM.

Pan, X., Chen, F., Wu, T., Tang, H., and Zhao, Z. 2009. The acid, Bile Tolerance and Antimicrobial property of Lactobacillus 
acidophilus NIT. J. Food Kontrol 20:598-602

Simanjuntak, P., Parwati, T., Bustanussalam, Prana, T.K., S. Wibowo, dan Shibuya, H. 2002, Isolasi dan kultivasi mikroba endofit penghasil senyawa alkaloid kinkona dari Chinchona spp. J. Mikrobiol. Indon, 7(2) : 27-30.

Strobel,G.A dkk, 1999. Cryptocandin, apotent antimycotic from endophytic fungus Cryptosporiopsis quercina. Microbiology 145 : 1919-1926.

Strobel, G. A. 2002, Microbial gifts from rain forests. Can. J. Plant Pathol, 24:14-20.

Strobel G.A., and Daisy B. 2003, Bioprospecting for Microbial Endophytes and Their Natural Products. Microbiol. and Mol. Biology Rev. 67(4):491-502.

Suraatmaja, S, 2007. Kapita Selekta Gastroenterologi Anak. Sagung Seto. Jakarta.

Tan, R.X., and Zou, W.X. 2001, Endophytes; a richsource of functional metabolites. Nat. Prod. Rep. 18:448-459.

Torar. S. S. Toy., dkk. 2015. Uji Daya Hambat Ekstrak Rumput Laut Gracilaria SP Terhadap Pertumbuhan Bakteri Staphylococcus aureus. Jurnal eGIGI, UNSRAT.

Yuniarti, T. 2008. Ensiklopedia Tanaman Obat Tradisional. Media pressindo. Yogyakarta: 65-67.

Wijaya, A. 2015. Serbuk Instan Ekstrak Daun Jambu mete (anacardium occidentalel.) Sebagai Antibakteri Helicobacter pylori pada Penyakit Grastitis. Jurnal Penelitian.

Volk, W. and Wheeler, A. 1988, Mikrobiologi Dasar, Erlangga, Jakarta.

Zhang, B., dkk, 1999, Discovery af small molecule insulin mimetic with antidiabetic activity in mice. Science 284:974-981. 